Araştırma Makalesi - Research Paper

\title{
INVESTIGATION OF THE NEUROPROTECTIVE EFFECT OF MELATONIN ON HIPPOCAMPAL NEURONAL INJURY DEVELOPING DUE TO THE NEUROTOXIC EFFECT OF CISPLATIN
}

\section{SİSPLATIN'IN NÖROTOKSIK ETKISINE BAĞLI GELISSEN HİPOKAMPAL NÖRON HASARINA KARŞI MELATONIN NÖROPROTEKTIF ETKINLIIGIININ ARAŞTIRILMASI}

\section{Ümit Ali MALCOK ${ }^{1}$, Başak BUYUK ${ }^{2}$}

\begin{abstract}
Özet
Sisplatin yaygın kullanılan ancak yaşam kalitesini düşüren etkileri olan bir antineoplastiktir. Özellikle nörotoksik etkileri, hastaların \%70'inde tedavi esnasında veya sonrasında bilişsel bozulmalara yol açmaktadır. Bu çalışmada melatoninin siplatin toksistesini azaltıcı etkinliği araştıııldı. Denek olarak 24 yetişkin erkek Wistar Albino ırkı sıçan kullanılarak 4 grup oluşturuldu. Sıçanlara 1. 5. 9. ve 13. günlerde ve $4 \mathrm{mg} / \mathrm{kg}$ dozunda intraperitoneal (ip) sisplatin verilerek nörotoksisite oluşturuldu. Tedavi grubuna ise $13 \mathrm{gün} 10 \mathrm{mg} / \mathrm{kg} / \mathrm{gün}$ dozunda ip melatonin uygulanarak gruplar karşılaştırıldı. 14. günde yapılan sakrifikasyon sonrası hipokampus dokuları alındı. Piknozis ve ödem skorları hesaplanarak sisplatin toksisitesi ve melatoninin etkinliği analiz edildi. Sham grubu ile Mel ve Cisp+Mel grupları arasında piknosis açısından anlamlı fark olmadığı ancak sisplatin verilen grupta belirgin düzeyde piknotik nöron artışı olduğu görüldü $(\mathrm{p}<0.01)$. Sisplatin verilen ratlarda hipokampus dokusundaki ödemin belirgin düzeyde arttığı buna karşın melatonin verildiğinde ödem skorlarının istatistiksel olarak anlamlı seviyede düştügü izlendi $(\mathrm{p}<0.01)$. Sisplatin ve melatonin benzer oksidatif ve apoptotik süreçleri zıt yönlerde etkilemektedir. Biz de çalışmamızda melatoninin sisplatin toksisitesi üzerine olan etkilerini inceledik ve melatoninin sisplatinin nörotoksik etkilerine karşı koruyucu etki gösterdiği sonucuna ulaştık. Ulaştığımız bu sonuç yaygın kullanılan bir kemoteropatik olan sisplatin, melatonin ile kombine edilerek kullanıldığında kanser hastalarının daha az nörotoksik yan etkilere maruz kalmasını sağlayacaktır.
\end{abstract}

Anahtar kelimeler: Sisplatin, melatonin, nörotoksisite, hipokampüs.

\begin{abstract}
Cisplatin is a widely used antineoplastic agent, but it has side effects that decrease quality of life. Its neurotoxic effects lead to cognitive disorders during or after treatment in $70 \%$ of the patients. In this study, the efficiency of melatonin to reduce cisplatin-induced toxicity was investigated. Four subject groups were established using 24 adult male Wistar Albino rats. Neurotoxicity was produced by administering intraperitoneal (ip) cisplatin on the $1 \mathrm{st}, 5 \mathrm{th}, 9$ th and 13 th day at a dose of $4 \mathrm{mg} / \mathrm{kg}$. Intraperitoneal melatonin was applied to the treatment group for 13 days at a dose of $10 \mathrm{mg} / \mathrm{kg} /$ day and the groups were compared. Following sacrification on the 14th day, hippocampal tissues were excised. Cisplatin toxicity and melatonin efficiency were analyzed by calculating pyknosis and edema scores. It was observed that there was no significant difference between the Sham, Mel and Cisp+Mel groups in terms of pyknosis, but a marked increase in pyknotic neurons occurred in the group which was given cisplatin $(\mathrm{p}<0.01)$. It was found that edema in the hippocampal tissue increased markedly in the rats which were given cisplatin, but edema scores statistically significantly decreased when melatonin was given $(\mathrm{p}<0.01)$. Cisplatin and melatonin influence the same oxidative and apoptotic processes in opposite directions. In our study, we examined the effects of melatonin on cisplatin-induced toxicity and concluded that melatonin showed protective action against cisplatin-induced neurotoxic effects. Our conclusion indicated that cancer patients would be exposed to fewer neurotoxic side effects when cisplatin, a widely used chemotherapeutic drug, is used in combination with melatonin.
\end{abstract}

Keywords: Cisplatin, melatonin, neurotoxicity, hippocampus.

Geliş Tarihi (Received Date): 22.04.2021, Kabul Tarihi (Accepted Date):07.05.2021, Basım Tarihi (Published Date): $30.05 .2021{ }^{1}$ Çanakkale Onsekiz Mart Üniversitesi, Tıp Fakültesi, Nöroşiruji Anabilim Dalı, Çanakkale ${ }^{2}$ İzmir Demokrasi Üniversitesi, Tıp Fakültesi, Histoloji ve Embriyoloji Anabilim Dal1, İzmir, E-mail: umalcok @ comu.edu.tr, ORCID ID’s: Ü.A.M; https:/orcid.org/0000-0002-1272-9654, B.B.; https:/orcid.org/0000-0003-1817-224. 


\section{INTRODUCTION}

Cisplatin (Cis-diammine-dichloro-platinum) is an antineoplastic agent that is used commonly in treatment of cancer. Cisplatin has many side effects. One of its side effects, that reduce quality of life, is the toxicity it causes in neural tissues. This neurotoxic effect is manifested by cognitive disorders that are observed during or after chemotherapy in $70 \%$ of the patients (Zandbergen $\mathrm{N}$ et al., 2019 p.790). Cisplatin irreversibly reduces protein 95 (PSD95) found in the postsynaptic region and the intensity of dendrite extensions with an increasing action depending on the dose and time period of drug exposure (Lomeli $\mathrm{N}$ et al., 2017 p.274). In addition, cisplatin was also shown to reduce the levels of the Brain-Derived Neurotrophic Factor (BDNF) which is a basic neuropeptide providing intracellular signaling related to neurogenesis, neuronal survival and synaptic plasticity in the brain (Amidi A et al., 2015 p.1). This injury developing in the neurons explains the cognitive disorders that develop following the use of cisplatin.

It is thought that use of cisplatin could become safer if reduction in the level of BDNF, which has an important role in the mechanism of neurotoxicity, can be prevented. It is known that melatonin (N-acetyl-5-methoxytriptamine) leads to an increase in BDNF levels (Luo $\mathrm{Y}$ et al., 2017 p.5951). Melatonin is known to have anti-inflammatory, antioxidative and antiapoptotic effects (Fernandez A et al., 2015 p.292). Melatonin was observed to have healing effects in many brain injuries including subarachnoid hemorrhage and Parkinson's disease (Ali T et al., 2015 p47, Dong Y et al., 2016 p.253). Based on this information, it was hypothesized that melatonin, which has neuroprotective effects, could reduce brain injury. In this study, we investigated the effects of melatonin on toxic injury in the hippocampi of rats which were given cisplatin.

\section{MATERIAL AND METHODS}

Ethics committee approval for this study was obtained from Çanakkale Onsekiz Mart University Animal Studies Local Ethics Committee with the decision numbered 2021/03-13. The National Institute of Health, Guide for the Care and Use of Laboratory Animals protocols were applied in the procedures performed on the subjects. Twenty-four adult male Wistar Albino rats with a weight of 275-325 g, which were obtained from Çanakkale Onsekiz Mart University Animal Production Unit, were used as experimental subjects. The study was planned to be conducted with rats using a randomized-controlled design. The subjects were kept in a setting with a temperature of $22 \pm 2{ }^{\circ} \mathrm{C}$, a relative humidity of $70 \pm 4 \%$ and a 12 -hour light-dark cycle for one week so that they could comply with the study. During this period, they were fed ad libitum with standard food and tap water. The subjects were randomly divided into four groups each including four rats.

The groups were named as sham, cisplatin, melatonin and cisplatin+melatonin. The sham group $(\mathrm{n}=6)$ was fed with normal diet for thirteen days. One $\mathrm{ml}$ of $1 \%$ ethanol solution, which was used while dissolving melatonin, was given by the intraperitoneal (i.p.) route once a day regularly. In addition, $1 \mathrm{ml}$ of isotonic saline solution, which was used while dissolving cisplatin, was administered by the i.p. route on the 1st, 5th, 9th and 13th days. In the cisplatin group (Cisp, $\mathrm{n}=6$ ), cisplatin was administered intraperitoneally at a dose of $4 \mathrm{mg} / \mathrm{kg}$ on the $1 \mathrm{st}$, 5th, 9th and 13th days. In the melatonin group (Mel, $n=6)$, melatonin, prepared daily by 
dissolving in $1 \%$ ethanol, was administered intraperitoneally at a dose of $10 \mathrm{mg} / \mathrm{kg} / \mathrm{day}$. In the Cisplatin+Melatonin group (Cisp+Mel, $n=6$ ), cisplatin was given on the 1st, 5th, 9th and 13th days (i.p., $4 \mathrm{mg} / \mathrm{kg}$ ) and melatonin was given additionally for 13 days (i.p., $10 \mathrm{mg} / \mathrm{kg} / \mathrm{day}$ ). Deep ketamine anesthesia $(60 \mathrm{mg} / \mathrm{kg})$ was applied before sacrification on the 14 th day in all groups. The entire brain was removed following decapitation and placed in $10 \%$ formalin solution for histopathological examination.

\subsection{Histopathological examination}

In preparing of brain tissue samples for microscopic examination, $10 \%$ neutral buffered formaldehyde solution was used. Tissue monitoring was performed in accordance with the procedure, and the tissues were embedded in paraffin. A 4-micron section thickness was preferred and the sections were dyed with Hematoxylin\&Eosin (H\&E). Olympus CX43 (Japan) microscope and computer-aided Leica Q Vin 3 program (imaging system) were used for examination of the tissues. In histopathological assessment, karyopyknosis in the neurons in the hippocampus and changes related to edema in the tissue were scored. This scoring was as follows: no visible change $=1$ point, presence of minimal or small change $=2$ points; presence of moderate change $=3$ points and presence of serious change $=4$ points. The sections evaluated were scored as described previously in the literature (Cankara FN et al., 2021 p.339).

\subsection{Statistical analysis}

The data were analyzed using SPSS Package Program version 20.0 (SPSS Inc, Chicago, IL, USA). Descriptive statistical tests were applied. Mean and standard deviation values were used for presentation. Compatibility of the variables with the normal distribution was evaluated using the Shapiro Wilk Test. As it was observed that the data were not distributed normally, the Kruskal Wallis test was used for in-group comparison. A value of $p<0,05$ was considered statistically significant.

\section{RESULTS}

In our study, we histopathologically found that cisplatin-induced hippocampal neurotoxicity was reduced by giving melatonin. It was observed that there was no significant difference between the Sham group and Mel and Cisp+Mel groups in terms of pyknosis ( $p>0.05$ ). However, a statistically significant difference was found between the Cisp group and

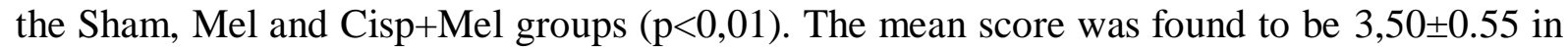
the Cisp group and 1,50 \pm 0.55 in the Cisp+Mel group. In conclusion, it was observed that cisplatin-induced pyknotic changes developing in the hippocampal neurons were significantly reduced when melatonin was given (Fig. 1, Table 1).

It was observed that there was no significant difference between the Sham group and the Mel and Cisp+Mel groups in terms of edema scores ( $p>0.05)$. In addition, there was also no significant difference between the Mel and Cisp+Mel groups. However, the difference between the Cisp group and the Sham, Mel and Cisp+Mel groups was statistically significant $(\mathrm{p}<0,01)$.

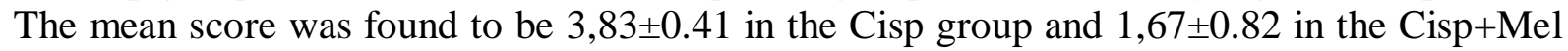
group. In conclusion, it was observed that cisplatin-related edema in the hippocampal tissue was reduced following administration of melatonin (Fig. 1, Table 1). 
Table 1. Histopathologic scoring of the hippocampus in brain.

\begin{tabular}{llllll}
\hline & Sham & Cisplatin & Melatonin & Cisplatin+Melatonin & $* \boldsymbol{p}$ \\
\cline { 1 - 3 } Pyknosis & $1.33 \pm 0.5$ & $3.50 \pm 0.5$ & $1.67 \pm 0.5$ & $1.50 \pm 0.5$ & $<0.01$ \\
Edema & $1.17 \pm 0.4$ & $3.83 \pm 0.4$ & $1.67 \pm 0.8$ & $1.67 \pm 0.8$ & $<0.01$
\end{tabular}

Histopathologic score values of the hippocampus are expressed as mean \pm standard deviation. *Comparison of the Cisplatin and Cisplatin+Melatonin groups. $\mathrm{p}<0.05$ was considered significant.

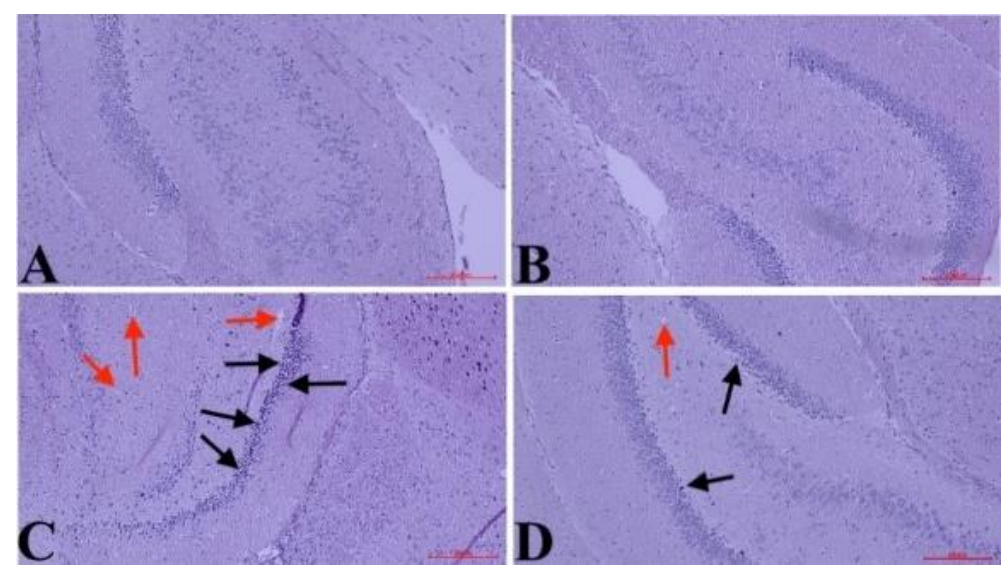

Figure 1: Light microscope images of the hippocampal region belonging to the experiment groups. A-the Sham group, B-the Melatonin group, C-the Cisplatin group, D-the Cisplatin+Melatonin group. Pyknotic cells are indicated by black arrows and edema regions are indicated by red arrows on the pictures (Magnification x100).

\section{DISCUSSION}

In our study, it was observed that edema and pyknotic neurons increased in the hippocampal tissues of the rats which were given cisplatin. When melatonin was given to the rats, to which cisplatin was administered, hippocampal edema and the number of pyknotic neurons were observed to reduce markedly. In conclusion, the finding that cisplatin-induced neurotoxic effects in the brain could be reduced by melatonin, was demonstrated for the first time with this study.

It is known that neurotoxic side effects, which increase depending on the dose and time period of treatment, occur in cancer patients treated with cisplatin (Amidi A et al., 2017 p.1). Memory and behavioral disorders may also be mentioned in addition to cognitive defects among cisplatin-induced neurological side effects in clinical practice (Troy L et al., 2000 p.29). In addition, cisplatin histopathologically inhibits neurogenesis in hippocampus, disrupts neurotransmitter production, and leads to damage in the neurons and glial cells (Liu Y et al., 2003 p.97). Neurons are more susceptible to stress-causing conditions compared to other cells because of their high lipid content and weak antioxidant defence systems (Krarup-Hansen A et al., 2007 p.1076). In the same study, it was also shown that cisplatin had an affinity for neurons and neuronal supportive tissues. In another study, it was shown that a marked decrease occurred in expression of proapoptotic and antiapoptotic genes in the hippocampi of rats 48 hours after 
administration of cisplatin (Manohar S et al., 2014 p.369). The aforementioned injury mechanisms play important roles in the neurotoxic effect of cisplatin.

\section{CONCLUSION}

Studies on combined use of cisplatin and neuroprotective compounds to decrease the injury caused by neurotoxic effects have been conducted in recent years. Melatonin is known to have antiapoptotic and neuroprotective effects on oxidative neuronal injury (Pazar A et al., 2016 p.74). Melatonin, which has antioxidant and positive effects in brain metabolism against stress, is an appropriate candidate molecule for this combination (Fernandez A et al., 2015 p.292, Dong Y et al., 2016 p.253). It is known that melatonin increases neuronal regeneration as well as having antiapoptotic efficiency (Luo Y et al., 2017 p.5951, Ali T et al., 2015 p.47).

In our study, the protective effects of melatonin on hippocampal injury developing after treatment with cisplatin were investigated. On histopathological evaluation we focused on the hippocampal region of the brain. The results we obtained showed that melatonin treatment reduced cisplatin-induced neurotoxicity and slowed pyknotic process in the hippocampal cells. Our results were also compatible with the neuroprotective effects obtained in studies in which melatonin was given to cases of subarachnoid hemorrhage and ototoxic injuries (Dong Y et al., 2016 p.253, Lopez-Gonzalez MA et al., 2000 p.73). Thus, melatonin, which is known to have neuroprotective effect, can be used to solve neurotoxic problems occurring in patients treated with cisplatin.

Studies have shown that edema in the brain and the blood-brain barrier permeability increase when cisplatin toxicity develops (Namikawa K et al., 2000 p.223, Kazak F et al., 2021 p.1). In our study, it was also observed that edema increased in the hippocampal tissues of the subjects, who were given cisplatin, in accordance with previous studies. In the literature, there are studies showing that edema decreases with administration of melatonin in injuries leading to neurotoxicity (Feng D et al., 2017 p.1, Dong Y et al., 2016 p.253). It was reported that melatonin showed this effect by reducing stress at the level of endoplasmic reticulum and by inhibiting autophagy (Ding K et al., 2014 p.1, Luo Y et al., 2017 p.5951, Dong Y et al., 2016 p.253, Fernandez A et al., 2015 p.292). As a result of the analysis of the data obtained by evaluation of edema in the hippocampal tissue in our study, we concluded that edema increased when cisplatin was given, and less edema occurred when cisplatin and melatonin were given in combination.

In the literature, studies on different issues related to cisplatin and melatonin have shown that they influence the same oxidative and apoptotic processes in opposite directions. However, we could not find any study demonstrating if melatonin reduces cisplatin toxicity in the brain tissue and especially in the hippocampus. In our study, we examined the effects of melatonin on cisplatin toxicity and concluded that melatonin showed protective action against cisplatininduced neurotoxic effects. Our results indicated that combined use of cisplatin, a widely used chemotherapeutic drug, with melatonin would help cancer patients to be exposed to fewer neurotoxic side effects. In addition, it would also be possible to increase quality of life as well as preserving cognitive levels with addition of melatonin to treatment protocols in cancer patients who have to be treated with cisplatin. This synergy will also provide safety for cisplatin treatment and an increase in drug exposure time. Our results should be supported by future 
studies, and transition processes for clinical application should be completed for melatonin to be included in the treatment protocol.

\section{REFERENCES}

Ali T., Kim MO. (2015). Melatonin ameliorates amyloid beta-induced memory deficits, tau hyperphosphorylation and neurodegeneration via PI3/Akt/GSk3beta pathway in the mouse hippocampus. J Pineal Res, 59, 47-59.

Amidi A., Hosseini SMH., Leemans A., Kesler SR., Agerbæk M., Wu LM., et al. (2017). Changes in Brain Structural Networks and Cognitive Functions in Testicular Cancer Patients Receiving Cisplatin-Based Chemotherapy. J Natl Cancer Inst, 109(12), 1-7. doi: 10.1093/jnci/djx085

Cankara FN., Günaydın C., Çelik ZB., Şahin Y., Pekgöz Ş., Erzurumlu Y., et al. (2021). Agomelatine confers neuroprotection against cisplatin-induced hippocampal neurotoxicity. Metab Brain Dis 36(2), 339-349. doi: 10.1007/s11011-020-00634-y

Ding K., Wang H., Xu J., Li T., Zhang L., Ding Y., et al. (2014). Melatonin stimulates antioxidant enzymes and reduces oxidative stress in experimental traumatic brain injury: the Nrf2-ARE signaling pathway as a potential mechanism. Free Radic Biol Med, 73, 1-11. doi: 10.1016/j.freeradbiomed.2014.04.031

Dong Y., Fan C., Hu W., Jiang S., Ma Z., Yan X., et al. (2016). Melatonin attenuated early brain injury induced by subarachnoid hemorrhage via regulating NLRP3 inflammasome and apoptosis signaling. J Pineal Res, 60, 253-262.

Feng D., Wang B., Wang L., Abraham N., Tao K., Huang L., et al. (2017). Pre- ischemia melatonin treatment alleviated acute neuronal injury after ischemic stroke by inhibiting endoplasmic reticulum stress-dependent autophagy via PERK and IRE1 signalings. J Pineal Res, 62(3), 1-13. doi: 10.1111/jpi.12395

Fernández A., Ordóñez R., Reiter RJ., González-Gallego J., Mauriz JL. (2015). Melatonin and endoplasmic reticulum stress: relation to autophagy and apoptosis. J Pineal Res, 59, 292-307.

Kazak F., Akalın PP., Yarım GF., Başpınar N., Özdemir Ö., Ateş MB., et al. (2021). Protective effects of nobiletin on cisplatin induced neurotoxicity in rats. Int $\mathbf{J}$ Neurosci, 8, 1-7. doi: 10.1080/00207454.2021.1896507

Krarup-Hansen A., Helweg-Larsen S., Schmalbruch H., Rørth M., Krarup C. (2007). Neuronal involvement in cisplatin neuropathy: prospective clinical and neurophysiological studies. Brain, 130, 1076-1088. https://doi.org/10.1093/brain/awl356

Liu Y., Hamaue N., Endo T., Hirafuji M., Minami M. (2003). 5-hydroxytryptamine (5-HT) concentrations in the hippocampus, the hypothalamus and the medulla oblongata related to cisplatin-induced pica of rats. Res Commun Mol Pathol Pharmacol, 113-114, 97-113.

Lomeli N., Di K., Czerniawski J., Guzowski JF., Bota DA. (2017). Cisplatin-induced mitochondrial dysfunction is associated with impaired cognitive function in rats. Free Radic Biol Med, 102, 274-286. doi: 10.1016/j.freeradbiomed.2016.11.046

Lopez-Gonzalez MA., Guerrero JM., Rojas F., Delgado F. (2000). Ototoxicity caused by cisplatin is ameliorated by melatonin and other antioxidants. J Pineal Res, 28(2), 73-80. doi: 10.1034/j.1600-079x.2001.280202.x

Luo Y., Peng M., Wei H. (2017). Melatonin Promotes Brain-Derived Neurotrophic Factor (BDNF) Expression and Anti-Apoptotic Effects in Neonatal Hemolytic Hyperbilirubinemia via 
a Phospholipase (PLC)-Mediated Mechanism. Med Sci Monit 23, 5951-5959. doi: 10.12659/msm.907592

Manohar S., Jamesdaniel S., Salvi R. (2014). Cisplatin inhibits hippocampal cell proliferation and alters the expression of apoptotic genes. Neurotox Res, 25(4), 369-80. doi: 10.1007/s12640013-9443-y

Namikawa K., Asakura M., Minami T., Okazaki Y., Kadota E., Hashimoto S. (2000). Toxicity of cisplatin to the central nervous system of male rabbits. Biol Trace Elem Res 74(3), 223-35. doi: 10.1385/BTER:74:3:223

Pazar A., Kolgazi M., Memisoglu A., Bahadir E., Sirvanci S., Yaman A., et al. (2016). The neuroprotective and anti-apoptotic effects of melatonin on hemolytic hyperbilirubinemiainduced oxidative brain damage. J Pineal Res 60(1), 74-83. doi: 10.1111/jpi.12292

Troy L., McFarland K., Littman-Power S., Kelly BJ., Walpole ET., Wyld D., et al. (2000). Cisplatin-based therapy: a neurological and neuropsychological review. Psychooncology, 9(1), 29-39. doi: 10.1002/(sici)1099-1611(200001/02)9:1<29::aid-pon428>3.0.co;2-z

Zandbergen N., de Rooij BH., Vos MC., Pijnenborg JMA., Boll D., Kruitwagen RFPM., et al. (2019). Changes in health-related quality of life among gynecologic cancer survivors during the two years after initial treatment: a longitudinal analysis. Acta Oncol, 58(5), 790-800. doi: 10.1080/0284186X.2018.1560498 